\title{
Tinjauan Kembali Pengaruh Tingkat Adopsi IFRS terhadap Persistensi Laba Perusahaan
}

(Studi Empiris di Negara ASEAN-5)

\author{
Zumratul Meini* \\ "Universitas Nasional \\ Pesona Depok Estate Blok Q2 No 3 Depok, Indonesia \\ E-mail: zum.meini@gmail.com
}

\begin{abstract}
Abstrak
Globalisasi menyebabkan arus keuangan dan investasi antar perusahaan dan antar negara semakin meningkat. Untuk memudahkan interaksi antar perusahaan antar negara tersebut maka dirasakan perlu bagi masing-masing negara untuk menggunakan standar laporan keuangan yang sama agar memudahkan semua pihak terkait untuk dapat membandingkan pelaporan lintas negara. IFRS merupakan standar pelaporan keuangan internasional yang dapat diadopsi oleh perusahaan di berbagai negara, namun belum semua negara mengadopsi standar tersebut. Penelitian ini bertujuan untuk menganalisis kembali bagaimana pengaruh tingkat adopsi IFRS terhadap kualitas laporan keuangan yang diukur dengan persistensi laba perusahaan khususnya yang terdaftar di Bursa Efek negara ASEAN-5. Kebaruan penelitian ini terletak pada metode penelitian dengan menggunakan Data Panel Dinamis, yang sudah mempertimbangkan efek antar waktu. Hasil penelitian ini diharapkan dapat dimanfaatkan sebagai masukan penting bagi para pembuat kebijakan di berbagai negara dalam mensikapi dampak adopsi IFRS terhadap kualitas laporan keuangan perusahaan.
\end{abstract}

\section{Kata kunci: IFRS, Persistensi Laba, ASEAN-5}

\begin{abstract}
Globalization causes the financial and investment flows between companies and countries to increase. To facilitate interaction between companies between countries, it is felt necessary for each country to use the same financial statement standards in order to facilitate all relevant parties to be able to compare cross-country reporting. IFRS is an international financial reporting standard that can be adopted by companies in various countries, but not all countries adopt these standards. This study aims to re-analyze how the influence of the level of IFRS adoption on financial quality reports as measured by the persistence of company earnings, especially those listed on the ASEAN-5 Stock Exchange. The novelty of the research lies in the research method using a Dynamic Panel Data, which has considered the effect over time. The results of this study are expected to be used as important input for policy makers in addressing the impact of IFRS adoption on the quality of corporate financial reports.
\end{abstract}

Keywords: IFRS, Earnings Persistence, ASEAN-5

\section{Pendahuluan}

Globalisasi merupakan proses interaksi dan integrasi antara manusia, perusahaan, dan pemerintahan dari negara yang berbeda, yang mana proses tersebut didorong oleh perdagangan internasional dan investasi dan dibantu oleh tekonologi informasi. Terintegrasinya negara-negara seluruh dunia menyebabkan tidak adanya rintangan batasan teritorial antar negara sehingga kegiatan perdagangan dan investasi lintas negara dapat dilakukan dengan mudah. Di negara ASEAN, dengan diberlakukannya Masyarakat Ekonomi ASEAN (MEA) pada akhir tahun 2015 juga menyebabkan arus bebas tidak hanya diberlakukan atas barang, namun juga jasa, investasi, tenaga kerja dan modal [1].

Fenomena tersebut membuat regulator, investor, perusahaan besar dan juga Kantor Akuntan Publik (KAP) di masing-masing negara menyadari pentingnya memiliki standar pelaporan keuangan internasional yang sama sehingga transaksi lintas negara menjadi mudah, dan lebih jauh lagi laporan keuangan dapat diperbandingkan sehingga memudahkan semua pihak untuk dapat menganalisisnya. 
Saat ini terdapat dua standar pelaporan keuangan yang dipakai di seluruh dunia, yaitu Generally Accepted Accounting Principles (GAAP) di Amerika dan International Financial Reporting Standards (IFRS) di beberapa negara Eropa. Dalam perkembangan terkini, IFRS kemudian semakin banyak digunakan sebagai standar pelaporan keuangan internasional tidak hanya di negara Eropa, namun juga di negara berkembang Asia.

Adopsi IFRS dirasakan memiliki kebermanfaatan terhadap pelaporan keuangan perusahaan. Namun bukti empiris yang meneliti tentang adopsi IFRS dan dampaknya terhadap kualitas laporan keuangan masih memberikan hasil yang beragam. Beberapa penelitian [2, 3, 4] membuktikan bahwa adopsi IFRS akan meningkatkan kualitas laporan keuangan termasuk persistensi laba. Informasi yang disajikan dengan menggunakan IFRS banyak menggunakan nilai wajar dan mensyaratkan pengungkapan laporan keuangan yang lebih ekstensif sehingga dapat meningkatkan kemampuan investor untuk memprediksi arus kas masa depan dan meningkatkan kandungan informasi dalam laba.

Namun ada juga yang menyatakan bahwa tidak ada perbedaan kualitas laba sebelum dan sesudah mengadopsi IFRS [5, 6]. Dengan demikian tidak ada pengaruhnya terhadap kualitas laba perusahaan ketika mereka mengadopsi IFRS ataupun tidak, meskipun standar pelaporan IFRS merupakan standar yang banyak diberlakukan di berbagai negara.

Terdapat pula pendapat yang menyatakan bahwa adopsi IFRS justru menurunkan kualitas laba perusahaa. Menggunakan standar IFRS menyebabkan volatilitas laporan keuangan meningkat (terkait orientasi fair value) sehingga menurunkan persistensi laba [7, 8, 33]. Penggunaan nilai wajar yang cukup ekstensif akan menyebabkan meningkatnya measurement error dan diskresi manajemen sehingga prediksi arus kas menjadi kurang akurat dan kandungan informasi laba menjadi kurang informatif [9].

Dengan masih beragamnya hasil penelitian tersebut, maka menarik untuk dilakukan penelitian kembali untuk memberikan gambaran yang jelas, bagaimana dampak adopsi IFRS terhadap kualitas laba perusahaan. Berbeda dengan penelitian sebelumnya, penelitian kali ini akan menggunakan metode penelitian yang lebih baik dibandingkan penelitian sebelumnya, sehingga diperoleh hasil yang lebih bisa mencerminkan kondisi empiris yang terjadi terkait pengaruh adopsi IFRS terhadap kualitas laba, khususnya persistensi laba perusahaan. Penelitian ini akan menggunakan model Data Panel Dinamis (DPD), yang sudah mempertimbangkan efek antar waktu dari persistensi laba, sehingga hasil estimasi menjadi lebih efisien.

\section{Landasan Teoritis}

\section{Teori Keagenan}

[10] menyatakan hubungan keagenan muncul ketika satu atau lebih individu (principal) mempekerjakan individu lain (agent) untuk memberikan suatu jasa dan kemudian mendelegasikan kekuasaan kepada agen untuk membuat suatu keputusan atas nama principal tersebut. Dalam level perusahaan (level mikro) maka manajer merupakan agent dan pemegang saham adalah sebagai principal. Sebagai agent, manajer secara moral bertanggung jawab untuk mengoptimalkan keuntungan para pemilik (principal), namun di sisi lain manajer juga mempunyai kepentingan untuk memaksimalkan kesejahteraan mereka, sehingga besar kemungkinan agent tidak selalu bertindak untuk kepentingan terbaik principal.

Masalah keagenan tersebut menyebabkan munculnya diskresi manajer dalam mengelola laporan keuangan, yang pada akhirnya akan menurunkan kualitas dari laporan keuangan perusahaan. Salah satu indikator laba dikatakan berkualitas adalah ketika laba tersebut sustainable dan persisten sehingga dapat dijadikan sebagai alat ukur yang berguna untuk menilai kinerja masa depan perusahaan $[11,12]$.

\section{Kualitas Laba}

Laba yang berkualitas didefinsikan sebagai laba yang dengan tepat dapat memberikan informasi tentang kinerja keuangan perusahaan yang relevan untuk pengambilan keputusan tertentu oleh pengambil keputusan tertentu pula [13]. Ketika terdapat distorsi dari manajemen dalam mengelola laba, maka dikatakan kualitas laba menjadi menurun, dan penurunan kualitas laba menjadikan informasi yang diberikan tentang kinerja keuangan perusahaan menjadi kurang relevan untuk pengambilan keputusan tertentu oleh pengambil keputusan tertentu pula, dan itu tentu akan merugikan para stakeholder.

Salah satu indikator laba dikatakan berkualitas adalah ketika laba tersebut sustainable dan persisten sehingga dapat dijadikan sebagai alat ukur yang berguna untuk menilai kinerja masa depan perusahaan [11, 12]. Menurut [14], laba yang persisten adalah laba yang dapat berulang di masa depan dan bertumbuh. Laba yang persisten juga merupakan input yang lebih baik untuk model valuasi ekuitas bagi para pemegang saham, sehingga semakin persisten laba semakin baik kualitas laba tersebut [15]. Informasi tentang laba yang persisten akan bermanfaat bagi investor sebagai salah satu penilaian terhadap kinerja perusahaan sehingga membantu mereka dalam menentukan investasi yang menguntungkan. 


\section{Tingkat Adopsi IFRS dan Persistensi Laba}

Penelitian terdahulu membuktikan bahwa tingkat adopsi IFRS berpengaruh positif terhadap kualitas laba perusahaan. Penelitian tersebut antara lain dilakukan oleh [16, 17], yang membuktikan bahwa setelah perusahaan mengadopsi IFRS, kualitas akuntansi mengalami perbaikan. Demikian juga penelitian [18] membuktikan bahwa pengadopsian IFRS dapat berguna bagi investor karena tingkat transparansi dan komparabilitas yang tinggi pada pelaporan keuangan berbasis IFRS dan dapat meningkatkan kualitas pelaporan keuangan. Dengan demikian, ketika suatu negara memutuskan untuk mengadopsi IFRS di negara nya, maka kualitas laba perusahaan di negara tersebut akan menjadi lebih baik. Perusahaan akan mampu memprediksi laba periode berikutnya, karena laba perusahaan cenderung persisten. Oleh karena itu dihipotesiskan:

H1: Adopsi IFRS akan meningkatkan Persistensi Laba perusahaan

\section{Metode Penelitian}

Penelitian ini merupakan penelitian persistensi laba pada level perusahaan namun menggunakan sampel perusahaan yang terdaftar di Bursa Efek 5 negara yang berbeda, yaitu Negara Indonesia, Malaysia, Thailand, Singapura dan Filipina.

Data yang akan digunakan dalam penelitian ini diperoleh dari Laporan keuangan tahun 2000-2015 diperoleh dari database Bloomberg OJK dan Thomson Reuters (datastream dan eikon) PDEB FEUI. Data Makro Ekonomi (variabel kontrol) diperoleh dari database Euromonitors PDEB FEUI, website ADB, World Bank, dan Bloomberg OJK

Metode pemilihan sampel adalah purposive sampling dengan kriteria perusahaan sebagai berikut: 1) Terdaftar di Bursa Efek di negara Asia Tenggara, yaitu Indonesia, Malaysia, Filipina, Thailand, dan Singapura (Pemilihan kelima negara didasarkan pada GDP nominal tertinggi di ASEAN); 2) Tidak termasuk dalam industri keuangan; 3) Laporan Keuangan berakhir per 31 Desember; 4) Terdapat kelengkapan data selama periode penelitian

\section{Variabel Penelitian dan Definisi Operasional Variabel Dependen: Persistensi Laba}

Variabel dependen pada penelitian ini adalah persistensi laba yang akan diukur dengan besarnya koefisien persistensi laba. Untuk mengukur koefisien persistensi laba perusahaan, penelitian ini mengikuti [19] dan [20] menggunakan pengukuran sebagai berikut:

Earning $_{t}=\alpha+\beta_{1}$ Earning $_{t-1}+\epsilon_{t}$ dimana: $\beta$ i merupakan ukuran persistensi laba, dan angka $\beta$ i tersebut menjadi variabel dependen EP.

Penelitian ini akan mengukur persistensi laba dengan menggunakan data tahun bergulir (rolling) lima tahun ke belakang, yang berarti 20 kuartal, Mengikuti [19, 20, 21].

\section{Variabel Independen: Adopsi IFRS}

Pengukuran adopsi IFRS dalam pengujian tambahan ini akan menggunakan pengukuran menggunakan dummy 1 untuk tahun dimana negara tersebut mengadopsi IFRS dan 0 untuk tahun lainnya. Tabel 1 menyajikan pengukuran waktu adopsi masing-masing negara di ASEAN-5.

TABLE I

PENGUKURAN LEVEL ADOPSI IFRS

\begin{tabular}{|l|c|l|}
\hline \multicolumn{1}{|c|}{ Negara } & $\begin{array}{c}\text { Tahun } \\
\text { Adopsi }\end{array}$ & \multicolumn{1}{|c|}{ Keterangan } \\
\hline Indonesia & 2012 & $\begin{array}{l}\text { Dummy 1 untuk 2012-2015 dan 0 } \\
\text { untuk 2005-2011 }\end{array}$ \\
\hline Malaysia & 2005 & Dummy 1 untuk 2005-2015 \\
\hline Filipina & 2005 & Dummy 1 untuk 2005-2015 \\
\hline Thailand & 2013 & $\begin{array}{l}\text { Dummy 1 untuk 2013-2015 dan 0 } \\
\text { untuk 2005-2012 }\end{array}$ \\
\hline Singapura & 2003 & Dummy 1 untuk 2005-2015 \\
\hline
\end{tabular}

\section{Spesifikasi Model}

Pengaruh IFRS terhadap persistensi laba perusahaan diuji dengan Model 1 (persamaan 2). Model ini mengacu pada $[19,20,22,23]$.

$E P_{i t}=\hat{a}_{1}+\hat{\beta}_{1} E P_{i t-1}+\hat{\beta}_{2} I F R S_{t}+\hat{\beta}_{3} l G D P_{t}+$ $\hat{\beta}_{4}$ Leverage $_{i t}+\hat{\beta}_{5}$ Size $+u_{i t}+\hat{v}_{i t}$.

$$
\begin{aligned}
& \text { Keterangan: } \\
& E P_{i t}=\text { Persistensi Laba perusahaan i pada periode } \mathrm{t} \\
& E P_{i t-1}=\text { Persistensi Laba perusahaan } \mathrm{i} \text { pada periode } \mathrm{t}- \\
& \mathrm{IFRSt}=\begin{array}{l}
\text { dummy } 1 \mathrm{jika} \text { pada periode } \mathrm{t} \text { negara } \\
\text { mengadopsi IFRS }
\end{array}
\end{aligned}
$$

Variabel Kontrol \& Variabel Instrumen

LGDP $_{\mathrm{t}}=$ Pertumbuhan ekonomi pada periode $\mathrm{t}$

Leverage $_{\text {it }}=$ Tingkat utang perusahaan pada periode $\mathrm{t}$

Size $_{\mathrm{it}}=$ Ukuran perusahaan pada periode $\mathrm{t}$

Infl $_{\mathrm{t}}=$ Tingkat inflasi pada periode $\mathrm{t}$

Infw $_{\mathrm{t}}=$ Tingkat inflasi dunia pada periode $\mathrm{t}$

Untuk menguji hipotesis penelitian yaitu terdapat pengaruh adopsi IFRS terhadap persistensi laba, pada model 1 dianalisis dengan melihat koefisien $\hat{\beta}_{2}$. Hipotesis tidak ditolak apabila $\hat{\beta}_{2}<0$.

\section{Metode Analisis}

Variabel dependen dalam penelitian ini adalah persistensi laba. Persistensi laba menunjukkan 
kemampuan perusahaan untuk tetap memperoleh laba dalam secara berulang, yang berarti perusahaan mampu menjaga stabilitas keuangan perusahaan di tengah kondisi perekonomian yang tidak pasti dan tingkat persaingan dalam industri. Pengukuran persistensi laba ditunjukkan dengan koefisien regresi laba sekarang terhadap laba periode sebelumnya (lihat persamaan 1). Semakin tinggi nilai koefisien regresi tersebut menunjukkan laba yang semakin persisten. Dengan mempertimbangkan bahwa persistensi laba merupakan koefisien regresi dari laba periode t-1 terhadap laba periode $\mathrm{t}$ (yang dalam ekonometri merupakan model $\mathrm{AR}(1)$ ), maka penulis berargumen bahwa akan terdapat hubungan antara persistensi laba periode $t$ dengan laba periode $\mathrm{t}-1$ yang digambarkan pada persamaan berikut:

$E P_{t}=\alpha+\beta_{1} E P_{t-1} \epsilon_{t}$

dimana EP adalah besarnya koefisien persistensi laba.

Dengan mempertimbangkan persistensi laba tahun sekarang akan dipengaruhi oleh persistensi laba tahun sebelumnya (lag), maka berbeda dengan penelitian sebelumnya, penelitian ini menggunakan panel data dinamis (DPD) karena sudah mempertimbangkan adanya efek antar waktu (dinamis) antara periode sekarang dengan periode sebelumnya. Penggunaan DPD menjadi tepat sebab dapat mengatasi masalah endogenitas yang muncul karena terdapat hubungan antara regresor lag dependen variabel dengan error/residu dari persamaan.

Model Data Panel Dinamis yang diusulkan oleh [24, 25] yang diestimasi dengan GMM (the generalized method of moments) dapat menghasilkan estimasi parameter yang lebih konsisten karena menggunakan instrumen variabel untuk menyelesaikan permasalahan endogenitas. Instrumen variabel akan memberikan estimasi dengan hasil yang efisien ketika ditambahkan lag dari variabel independen sebagai variabel instrumen. Selain itu, diperlukan juga variabel lain di luar lag variabel independen sebagai variabel instrumen yang memiliki hubungan dengan variabel dependen. Dalam model GMM, jumlah instrumen variabel harus lebih banyak dari jumlah variabel independen dalam model

Dalam penelitian ini akan digunakan beberapa kandidat instrumen variabel yang bisa mempengaruhi persistensi laba, antara lain ekspansi dan pertumbuhan ekonomi dunia.

Model dinamis dapat ditulis sebagai:

Yit $=\alpha i+\beta$ Xit $+\gamma$ Yit $1+\varepsilon i t$.

Untuk dapat mengestimasi persamaan yang memiliki masalah endogenitas, persyaratan identifikasi harus dipenuhi. Untuk mengetahui apakah suatu persamaan dapat diestimasi parameternya maka perlu dicek status identifikasinya, apakah under identified, exact identified, overidentified.

Beberapa pengujian yang dilakukan dalam DPD adalah:

\section{Uji Sargan}

Instrumen variabel harus valid dan relevan. Uji Sargan digunakan untuk mengetahui validitas penambahan instumen variabel. Dan menjadi valid adalah jika jumlah instrumen melebihi jumlah variabel eksogen (kondisi overidentifying restriction). Hipotesisnya adalah:

\section{HO: Kondisi overidentifying restriction dalam pendugaan model valid \\ H1: Kondisi overidentifying restriction dalam pendugaan model tidak valid}

Instrumen variabel juga harus relevan. Semakin kuat hubungan antara instrumen $\mathrm{Z}$ dan variabel eksogen $\mathrm{X}$, maka semakin kuat identifikasi model. Sebaliknya instrumen yang tidak relevan menunjukkan instrumen yang lemah, sehingga instrumen menjadi tidak tepat, standar error bisa menjadi beberapa kali lebih besar dan t statistik juga menjadi beberapa kali lebih kecil [26].

\section{Uji Hausman (Uji Endogenitas)}

Uji Hausman pada prinsipnya menyediakan cara untuk menguji apakah regressor (variabel $\mathrm{X}$ ) adalah endogenous. Ketika terdapat perbedaan yang sedikit saja antara estimator OLS dan estimator IV, maka tidak perlu digunakan instrumen variabel, dan kita dapat menyimpulkan bahwa regressor adalah eksogenous. Jika terdapat perbedaan yang harus dipertimbangkan, maka diperlukan instrumen dan regressor adalah endogenous.

HO: regressor adalah exogenous

H1: regressor adalah endogenous

\section{Hasil Penelitian Dan Pembahasan}

\section{Pemilihan Sampel}

Metode pemilihan sampel adalah purposive sampling. Data difokuskan pada perusahaan yang terdaftar di Bursa Efek Indonesia (BEI), Malaysia (KLCI), Singapura (STI), Thailand (SET), dan Philipina (PSE). Total perusahaan yang terdaftar adalah sebanyak 2.876 perusahaan. Jumlah seluruh sampel adalah sebanyak 45.089 perusahaan-triwulanan.

\section{Deskriptif Statistik}

Gambaran umum nilai masing-masing variabel disajikan dalam tabel deskriptif statistic sebagai berikut: 
TABLE 2

DESKRIPTIF STATISTIK

\begin{tabular}{lccccc}
\hline Variabel & Mean & Median & Max. & Min. & $\begin{array}{l}\text { Std. } \\
\text { Dev }\end{array}$ \\
\hline EP & 0.1486 & 0.0981 & 1.886 & -1.429 & 0.3683 \\
\hline IFRS & 0.7052 & 1.0000 & 1.000 & 0.0000 & 0.4559 \\
\hline LGDP & 453547 & 193183 & 22387 & 1672.1 & 65418 \\
\hline Lev & 0.4531 & 0.4447 & 1.4871 & 0.0327 & 0.2428 \\
\hline Size & 20.119 & 19.182 & 29.273 & 14.501 & 3.5422 \\
\hline $\begin{array}{l}\text { Keterangan Tabel: } \\
\text { EP= Persistensi Laba; IFRS= dummy 1 jika Adopsi IFRS dan 0 } \\
\text { jika tidak adopsi IFRS; LGDP= pertumbuhan ekonomi diukur } \\
\text { dengan Logaritma natural GDP Riil; Lev= Leverage; Size= } \\
\text { ukuran perusahaan diukur dengan logaritma natural penjualan }\end{array}$ \\
\hline
\end{tabular}

\section{Hasil Penelitian}

\section{Uji Sargan dan Uji Hausman}

Pada penelitian ini dilakukan Uji Sargan untuk mengetahui validitas penambahan instrument variabel (IV), jika jumlah IV melebihi jumlah variabel eksogen, kondisi over identifikasi valid diterima. berarti Uji Sargan tentang restriksi over identifikasi dapat dilakukan. Cara lain adalah dengan melihat $\mathrm{p}$ value dari hasil uji Sargan, jika lebih dari 0,05 maka Ho diterima, berarti over identifikasi dapat diterima. Berdasarkan hasil uji Sargan pada Tabel 3 diperoleh hasil bahwa penambahan instrumen yang digunakan dalam model penelitian adalah valid.

Pada penelitian ini dilakukan uji Hausman pada Tabel 3 untuk mengetahui apakah regressor (variabel $\mathrm{X}$ ) adalah endogenous. Hasil uji Hausman menunjukkan terdapat korelasi antara lag variabel dependen dengan residu (regressor adalah endogenous). Hal ini berarti bahwa diperlukan penggunaan model data panel dinamis sehingga metode GMM dalam model ini adalah efisien.

\section{Pengujian Hipotesis}

Hasil pengujian pada Tabel 3 menunjukkan koefisien Adopsi IFRS signifikan pada $\alpha=1 \%$ dan bernilai negatif. Dengan demikian Hipotesis 1 yang menyatakan bahwa suku bunga berpengaruh negatif terhadap persistensi laba menjadi ditolak. Berdasarkan hasil pengujian hipotesis, tidak terbukti bahwa adopsi IFRS dapat meningkatkan persistensi laba. Hasil pengujian menunjukkan bahwa adopsi IFRS menyebabkan persistensi laba perusahaan menjadi menurun.
TABLE 3

HASIL REGRESI

\begin{tabular}{|c|c|c|c|}
\hline \multicolumn{4}{|c|}{$\begin{array}{c}E P_{i t}=\hat{a}_{1}+\hat{\beta}_{1} E P_{i t-1}+\hat{\beta}_{2} I F R S_{t}+\hat{\beta}_{3} l G D P_{t}+\hat{\beta}_{4} \text { Leverage }_{i t} \\
+\hat{\beta}_{5} \text { Size }+u_{i t}+\hat{v}_{i t}\end{array}$} \\
\hline Variabel & $\begin{array}{c}\text { Ekspektasi } \\
\text { Tanda }\end{array}$ & Koef. & Prob. \\
\hline $\mathrm{C}$ & & $-0,1047^{* * *}$ & 0,0025 \\
\hline $\mathrm{EP}(-1)$ & + & $0,9394^{* * *}$ & 0,0000 \\
\hline IFRS & + & $-0,0075^{* * *}$ & 0,0072 \\
\hline LGDP & + & $0,0178^{* * *}$ & 0,0401 \\
\hline LEV & - & 0,0001 & 0,4913 \\
\hline SIZE & + & $0,0060^{* * *}$ & 0,0021 \\
\hline Adjusted R-squared & & 0,8028 & \\
\hline Instrument rank & & 1052 & \\
\hline $\operatorname{Prob}(\mathrm{J}$-statistic) & & 0,0861 & \\
\hline
\end{tabular}

\section{Keterangan tabel:}

$\mathrm{EP}=$ Persistensi Laba; IFRS= dummy 1 jika Adopsi IFRS dan 0 jika tidak adopsi IFRS; LGDP= pertumbuhan ekonomi diukur dengan Logaritma natural GDP Riil; Lev= Leverage; Size= ukuran perusahaan diukur dengan logaritma natural penjualan.

Instrumen rank dan Prob (J-statistic) merupakan Uji Sargan. Jika jumlah instrumen melebihi jumlah variabel eksogen (kondisi overidentifying restriction) maka instrument adalah valid. Prob (J-statisic) $\rho>5 \%$ maka terima Ho (Ho: Kondisi overidentifying restriction dalam pendugaan model valid).

*** Signifikan pada level 1\% (one-tailed test); ** Signifikan pada level $5 \%$ (one-tailed test); * signifikan 10\% (one-tailed test)

Penjelasan mengapa adopsi IFRS dapat menyebabkan persistensi laba perusahaan menjadi menurun antara lain karena IFRS menetapkan nilai berdasarkan fair value yang dapat saja menyebabkan harga menjadi tidak stabil, karena mengikuti berapa nilai wajar yang terkandung pada suatu asset perusahaan. Volatilitas laporan keuangan menjadi meningkat, sehingga menurunkan persistensi laba perusahaan. Dengan demikian temuan ini mengkonfirmasi hasil penelitian $[7,8,29]$.

Variabilitas laba yang lebih besar sehingga menyebabkan laba kurang persisten, mengakibatkan prediktabilitas yang lebih rendah, dan banyak lagi pengakuan kerugian tepat waktu setelah adopsi IFRS $[30,31]$. Namun demikian temuan ini tidak menyiratkan adopsi IFRS menyebabkan kualitas laba menjadi lebih rendah. Persistensi yang lebih rendah mungkin terkait dengan pengurangan praktik perataan laba, yang jelas menghasilkan kualitas pelaporan yang lebih tinggi. Tentu saja untuk memverifikasi hasil ini diperlukan penelitian lebih lanjut lagi.

\section{Kesimpulan}

Penelitian ini bertujuan untuk menganalisis kembali bagaimana pengaruh tingkat adopsi IFRS terhadap kualitas laporan keuangan yang diukur dengan persistensi laba. Penelitian ini mengambil sampel pada 
perusahaan khususnya yang terdaftar di Bursa Efek negara ASEAN-5 tahun 2005-2015. Berbeda dengan penelitian sebelumnya, penelitian ini menggunakan Data Panel Dinamis (DPD) sehingga diharapkan dapat memberikan hasil penelitian yang lebih efisien.

Berdasarkan hasil penelitian, tidak terbukti bahwa adopsi IFRS dapat meningkatkan persistensi laba. Hasil pengujian menunjukkan bahwa adopsi IFRS menyebabkan persistensi laba perusahaan menjadi menurun. Hasil ini bisa disebabkan karena IFRS menetapkan nilai berdasarkan fair value yang dapat saja menyebabkan harga menjadi tidak stabil, karena mengikuti berapa nilai wajar yang terkandung pada suatu asset perusahaan. Hasil penelitian ini diharapkan dapat dimanfaatkan sebagai masukan penting bagi para pembuat kebijakan di berbagai negara dalam mensikapi dampak adopsi IFRS terhadap kualitas laporan keuangan perusahaan.

Penelitian selanjutnya dapat dilakukan dengan membuktikan apakah penurunan persistensi laba akibat adopsi IFRS menunjukkan penurunan kualitas laba perusahaan. Penelitian selanjutnya dapat meneliti apakah perusahaan melakukan perataan laba atau tidak di periode yang sama. Penelitian selanjutnya juga dapat menguji apakah adopsi IFRS berpengaruh terhadap manajemen laba perusahaan. Dengan demikian akan diperoleh hasil yang lebih komprehensif bagaimana dampak IFRS terhadap kualitas laba perusahaan.

\section{Daftar Pustaka}

A. Meini, Z., Safuan, S., Dewo, S. A., \& Diyanti, V. (2018). Business cycles and earnings persistence: evidence from the ASEAN-5 countries. International Journal of Economics and Management, 12(November), 105-118.

B. Chen, H., Tang, Q., Jiang, Y., \& Lin, Z. (2010). The Role of International Financial Reporting Standards in Accounting Quality: Evidence from the European Union. Journal of International Financial Management \& Accounting, 21(3), 157.

C. Hai Q. Ta. (2014). Effects of IFRS adoption on earnings quality: Evidence from Canada, (June), 209.

D. Farichah, F. (2017). Relationship of earnings management and earnings quality before and after IFRS implementation in Indonesia. European Research Studies Journal, 20(4), 70-81. https://doi.org/10.35808/ersj/875

E. Den Besten, P. S., Georgakopoulos, G., Vasileiou, K. Z., \& Ereiotis, N. (2015). The Impact of IFRS Adoption on Earnings Quality: A Study Conducted on Foreign Issuers in the United States. International Business Research, 8(11), 139. https://doi.org/10.5539/ibr.v8n11p139

F. Shobriati, I., \& Siregar, S. V. N. P. (2016). Pengaruh Tingkat Adopsi IFRS dan Proteksi Investor terhadap Persistensi Laba: Analisis Lintas Negara Emerging Markets. Jurnal Manajemen Teknologi, 15(3), 324-344. https://doi.org/10.12695/jmt.2016.15.3.7

G. Ball, R. (2010). International Financial Reporting Standards (IFRS): Pros and Cons for Investors. Accounting and Business Research, Forthcoming, 53(9), 1689-1699. https://doi.org/10.1088/17518113/44/8/085201

H. Barth, M. E., Landsman, W. R., Lang, M. H., \& Williams, C. D. (2012). Are IFRS-based and US GAAP-based Accounting Amounts Comparable? SSRN Electronic Journal. https://doi.org/10.2139/ssrn.1585404

I. Wang, X., Young, D., \& Zhuang, Z. (2008). The Effects of Mandatory Adoption of International Financial Reporting Standards on Information Environments The Effects of Mandatory Adoption of International Financial Reporting Standards on Information Environments.

J. Jensen, M. C., \& Meckling, W. H. (1976). Theory of the Firm : Managerial Behavior, Agency Costs and Ownership Structure. Journal of Financial Exconomics, 3(December 2000), 305-360. https://doi.org/http://dx.doi.org/10.1016/0304405X(76)90026-X

K. Nelson, M. W., \& Skinner, D. J. (2013). How should we think about earnings quality? A discussion of "Earnings quality: Evidence from the field." Journal of Accounting and Economics, 56(2-3), 34-41. https://doi.org/https://doi.org/10.1016/j.jacceco.20 13.10.003

L. Dichev, I. D., Graham, J., \& Harvey, C. R. (2013). Earnings Quality: Evidence from the Field Earnings Quality : Evidence from the Field.

M. Dechow, P., Ge, W., \& Schrand, C. (2010b). Understanding earnings quality: A review of the proxies, their determinants and their consequences. Journal of Accounting and Economics, 50(2-3), 344-401.

https://doi.org/10.1016/j.jacceco.2010.09.001

N. Penman, S. (2013). Financial Statement Analysis and Security Valuation. https://doi.org/10.2308/iace-10329

O. Dechow, P., Ge, W., \& Schrand, C. (2010a). 
Understanding earnings quality: A review of the proxies, their determinants and their consequences \$. Journal of Accounting and Economics, 50(2-3), 344-401.

https://doi.org/10.1016/j.jacceco.2010.09.001

P. Narktabtee, K., \& Patpanichchot, S. (2011). The Impact Of Country-Level vs Firm-Level Factors On The Effectiveness Of IFRS Adoption: The Case Of European Union. International Business \& Economics Research Journal (IBER), 10(10), 79. https://doi.org/10.19030/iber.v10i10.5985

Q. Zeghal, D., Chtourou, S. M., \& Fourati, Y. M. (2012). The effect of mandatory adoption of IFRS on earnings quality: Evidence from the European union. Journal of International Accounting Research, 11(2), 1-25. https://doi.org/10.2308/jiar-10221

R. Mita, A. F., Utama, S., Fitriany, F., \& Wulandari, E. R. (2018). The adoption of IFRS, comparability of financial statements and foreign investors' ownership. Asian Review of Accounting, 26(3), 391-411. https://doi.org/10.1108/ARA-04-20170064

S. Francis, J., LaFond, R., Olsson, P., \& Schipper, K. (2004). Costs of Capital and Earnings Attributes. The Accounting Review, 79(4), 967-1010. https://doi.org/https://doi.org/10.2308/accr.2004.7 9.4.967

T. Persakis, A., \& Iatridis, G. E. (2015). Earnings quality under financial crisis: A global empirical investigation. Journal of Multinational Financial Management, $30, \quad 1-35$. https://doi.org/10.1016/j.mulfin.2014.12.002.

U. Johnson, M. F. (1999). Business cycles and the relation between security returns and earnings. Review of Accounting Studies, 4(2), 93-117. https://doi.org/10.1023/A:1009649018325

V. Lev, B. (1983). Some economic determinants of the series properties of earnings. Journal of Accounting \& Economics, 5, 31-48.

W. Baginski, S. P., Lorek, K. S., Willinger, G. L., \& Branson, B. C. (1999). The Relationship Between Economic Characteristics and Alternative Annual Earnings Persistence Measures. The Accounting Review, 74(1), 105-120. https://doi.org/10.2308/accr.1999.74.1.105

X. Blundell, R., \& Bond, S. (1998). Initial conditions and moment restrictions in dynamic panel data models. Journal of Econometrics, 87(1), 115-143. https://doi.org/10.1016/S0304-4076(98)00009-8

Y. Ahn, S., \& Schmidt, P. (1997). Efficient Estimation of Dynamic Panel Data Models: Alternative Assumptions and Simplified Estimation. Journal of Econometrics (Vol. 76). https://doi.org/10.1016/0304-4076(95)01793-3

Z. Cameron, A. C., \& Trivedi, P. K. (2010). Microeconometrics using Stata Revised Edition. Stata Press. https://doi.org/10.1016/S03044076(00)00050-6

AA. Doukakis, L. C. (2010). The persistence of earnings and earnings components after the adoption of IFRS. Managerial Finance, 36(11), 969-980.

https://doi.org/10.1108/03074351011081286

BB. Barth, M. E., Landsman, W. R., \& Lang, M. H. (2008). International accounting standards and accounting quality. Journal of Accounting Research, 46(3), 467-498. https://doi.org/10.1111/j.1475679X.2008.00287.x

CC. Hung, M., \& Subramanyam, K. R. (2007). Financial statement effects of adopting international accounting standards: The case of Germany. Review of Accounting Studies, 12(4), 623-657. https://doi.org/10.1007/s11142-0079049-9 